\title{
4 From Industrial Worker to Corporate Manager: The Ungendering of Andy Warhol's Masculinity
}

\begin{abstract}
This article explores Andy Warhol's masculinity as it was shaped and performed in the early years of his artistic career. While Warhol's gender identity, like his art, is often understood as a personal, artistic and cultural manifestation of his queerness, I argue that its coded nature forces us to look for other models of manhood that he employed. In this article, I chart the changing relationships between Warhol's modes of artistic production, the kind of artistic subjectivity they implied, and the ways in which these shaped his masculinity. I point to a transformation in each of these categories: a shift from Fordist to post-Fordist modes of production; a shift from the Modernist ideal of the artist as an author to the absence of authorship; and a shift from the model of the male artist/worker, to the model of the male artist as a dandy. The first part of this article locates Warhol within a wider shift in both artistic and non-artistic production that took place during the first half of the 1960s: the emergence of a new generation of artists that reacted against Abstract Expressionistic models of artistic subjectivity. The second part focuses on changes in Warhol's artistic practice and masculinity, from his first move into the Factory to him gaining public and professional recognition in the mid-1960s.
\end{abstract}

\section{Introduction}

The public image of Andy Warhol, one of the most influential and successful artists in the second half of the twentieth century, is traditionally coloured by his queerness. That is, his Camp aesthetic, his provocative lifestyle and his interest in celebrity culture as well as in outsiders of the heteronormative order. The proliferation of queer studies in the 1990s, followed by the growing interest of the mainstream media in queer culture, expanded this reading to a point where Warhol's masculinity is discussed only in terms of his sexuality. Warhol's gender identity as well as his art is understood today mainly as personal, artistic and cultural manifestations of his queerness (Joseph 2005; Crimp 2012; Schoonover 2012; Doyle 2015).

The importance of Warhol's contribution to queer culture cannot be underestimated, nor the value of reading his art from a queer perspective. As Joseph 
(2005), Crimp (1999), and others have shown, these readings allow us to articulate the production of desire in capitalism and to appreciate the political urgency of Warhol's queer aesthetic. At the same time, it is known that in conservative America of the late 1950s and early 1960s, Warhol's queerness was greatly "coded". Its signifiers were legible only to those fluent in the imagery of gay and queer culture. The question is, therefore, what other elements figured in the construction of Warhol's masculinity and how did they play out in the formative body of his artistic career? What were the models of masculinity against which he shaped his masculinity? Which elements of this masculinity did he make visible throughout his career and which remained hidden?

To answer these questions, we must look at other crucial aspects of masculine identity construction. In Warhol's case, as I will demonstrate, it was the realm of production - both artistic and non-artistic - which shaped the forms of masculinity he presented. Warhol's model of masculinity changed dramatically between his early experimentations in art from 1962 to 1963 and his public success between 1965 and 1966. To articulate this change, we should look at shifts in artistic practices (artistic labour) during the early years of his career, and the models of artistic subjectivity that these practices are linked with. Only then will we be able to explain the construction of Warhol's masculine identity as a reaction, on the one hand, to the model shaped by his predecessors, and as an intervention in emerging corporate managerial practices, on the other.

This line of inquiry is built on two interrelated assumptions. The first is that artistic production is part of the general division of work in a society. This means that, although art is in many respects an autonomous realm of production, it is not necessarily produced for the creation of surplus value and it is still influenced by modes of non-artistic production. John Roberts goes as far as to argue that in the twentieth century, art defined its critical perspective by its 'attitude' towards hegemonic modes of production in society. Artists adopt, manipulate and reject techniques and practices which come from different realms of production, in order to position themselves in the world (Roberts 2007, 2).

The second assumption, made by various scholars from different fields, has to do with the mutual fashioning of labour and gender. According to that premise, the workplace is a site where gender identity, as well as gender hierarchies, are produced and reproduced. As Kathy Weeks argues, "it is not merely a matter of bringing one's gendered self to work but of becoming gendered in and through work” (Weeks 2011, 10). Gender can determine our approach towards the work we do, just as easily as our career choices and work play an important role in the way we understand ourselves as gendered subjects. Once the rhetoric of work became fundamental in the formation of "collective gender identity" (Baron 2006, 150), the workplace turned into a focal point for the construction of masculinity. 
Put differently, the workplace is central to the "forming, nurturing, widening, and deepening” of masculine culture (Meyer 2016, 2). Following Connell and others, masculinity is understood here as a social construction that is always relational: it is composed of acts, attitudes, social roles and relationships that are negotiated in a given social context. Identifications, similarities and differences among men arise within a specific life situation and within the system of gender relations (Baron 2006; Connell 2005; Kimmel 1996). Hence, the career we pursue is in many respects influenced by these gender relations and shapes them in return.

Bringing these notions into research on masculinity and artistic labour means that we see artists and their masculinity as shaped by the gendered history of their profession, their actual work environment and their hands-on work practices. This is extremely relevant when discussing the transformation into a new economic era and the modes of production linked with it. The transformation from the industrial order to a corporate one was discussed at length as a 'crisis' of masculinity: the new white-collar corporate man was considered less manly than the industrial worker (Forth 2008, 204; Baron 2006, 145-146). However, the question of how this shift constructed a new model of the male artist remained utterly unexplored. By taking Warhol's career as a case study, I will articulate these changing relationships between artistic practice, artistic subjectivity, and models of masculinity.

Warhol's early career, between 1963 and 1968, will be the focus of this article. These were the years of Warhol's first studio, the Factory (also known as the Silver Factory), and the years of the famous Elizabeth Taylor, Marilyn Monroe and Elvis Presley portraits; the Campbell's Soup Cans and Brillo boxes and the experimental films Sleep (1963), Empire (1964) or the Screen Tests project (1964-1966). These years form the most important phase in Warhol's career: his innovative use of the silkscreen technique, his unique cinematic language, and his influential model of artistic subjectivity were developed then, alongside his model of masculinity. Whereas scholarly work on Warhol often takes his aesthetic as an object of inquiry, the current article will focus on Warhol's artistic practice: his process and method of artmaking.

In the following, I delineate the changing relationship between Warhol's modes of artistic production, the kind of artistic subjectivity they implied, and the way in which they shaped his model of masculinity. To do so, I point to a transformation in each of these categories: a shift from Fordist to post-Fordist modes of production; a shift from the Modernist idea of the artist as author to a notion of the artist as absent author; and a shift from the model of the male artist as associated with the figure of the worker to the model of the male artist as a dandy. The first part of this article locates Warhol within a wider shift in both artistic and non-artistic production, which took place around the first half of the 1960s: the emergence of a new generation of artists, as a reaction to the 
generation of Abstract Expressionist artists and their models of artistic subjectivity. The second part focuses on changes in Warhol's artistic practice and masculinity, from his first move into the Factory, to him winning public and professional recognition in the mid-1960s.

\section{The Language of Work: Artistic Subjectivity and the Model of the Male Artist between Abstract Expressionism and the Neo-avant-garde}

By the beginning of the 1960s, a dramatic shift had taken place in the American art world. A new generation of artists came to see themselves not as "artists producing (in) a dreamlike world, but as workers in capitalist America" (Molesworth 2003, 27). The corporatisation of American culture, the flourishing of a new consumerist society and the booming post-war economy "placed extraordinary pressures on artists to redefine themselves and their work, and often they did so by thinking through and acting out the profound transformations of late-twentiethcentury labour in their work" (Molesworth 2003, 27). Unlike their predecessors, the Abstract Expressionism's generation of painters, who adopted the Modernist convention of the heroic, eccentric and lonely artist, the new generation of artists explored ways to become part of the new capitalist order. Frank Stella presented himself as an executive artist, Donald Judd as a worker-designer and Robert Smithson as a worker-researcher (Roberts 2004, 342). Accordingly, Andy Warhol named his studio "The Factory". These artists adopted "the language of work as opposed to that of art", as Helena Molesworth puts it (Molesworth 2003, 25).

The process by which major corporations became the social institutions that represented the American spirit, was part of the transition from a Fordism mode of production to a post-Fordist one (Marchand 1998, 360): a shift from a scientific and rational production process, based on assembly-line logic, to a new capitalist order of "flexible accumulation" (Harvey 1990, 147). The logic of the Fordist production, which fuelled the rapidly growing consumerist culture of the 1960s was still the dominant mode of production, but a project-based, collective work with non-binding connections between the employers and employees, was on the rise (Harvey 1990, 132-135). Hollywood was one of the first industries to implement this shift. After running the film industry for several decades, in a sequential assembly-line style, the major studios reorganised their production process. As early as the mid-1950s, every production was organised and assembled from scratch, based on its specific needs (Regev 2018, 
197-199). "Instead of big, vertically integrated companies, in the new flexible pattern, any industry revolves around a small core of employees with permanent status and a larger periphery of easily exchangeable part-time workers" (Regev 2018, 198). Flexible accumulation meant an adaptable, ad hoc collective cooperation, in which the manager holds the knowledge required to complete the task, hence becoming the most dominant figure in the production process.

Yet, for the artists, the adaptation of the linguistic and aesthetic rhetoric of the corporate world was first and foremost a way to attack the Modernist conception of artistic subjectivity. In post-war America, this conception was defined and manifested by Abstract Expressionism, which was considered the first original American contribution to Modernism in art, and the mainstream of American art at the time. The work of artists like Jackson Pollock, Willem de Kooning and Mark Rothko was often defined by the use of large-scale canvas, expressive brushstrokes and paint drips, rather than meticulous, pre-configured work. The expressionist painting was understood as an expression of the artist's inner self in a moment of transgression. In the case of Pollock, who became the emblem of Abstract Expressionism, his paint drips were understood by art writers as a direct extension of the artist's body and soul (Rosenberg 1952/2003, 590). Instead of painting, they were an act of mark-making: an unmediated self-expression projected onto the canvas as a representation of unconscious impulses. Following this reading of the artistic act, the artist was defined as a heroic figure who overcame personal impulses by turning them into great art (Barber 2004, 148-154).

Turning to the world of labour allowed the post-war artists to eliminate the expressive model of Abstract Expressionism. They developed different kinds of "mechanical" productions, first manual and then conceptual, which diminished the role of the artist as the source of creativity for the artwork. Whether in the form of a score for performance (Fluxus), instructions for drawings (conceptual), or copying everyday imagery (Pop), they all constrained the artistic act by a set of technical procedures or conceptual rules, and the artist's role was to work within these limits or oversee their materialisation. This 'mechanical' type of production changed the aesthetic of the artistic object dramatically, yet it also served as the prime strategy for attacking notions of skill, authorship and originality that were linked to Abstract Expressionist artists (Buchloh 2001, 33). It was a direct intervention in the conception of the artists' artistic subjectivities as "solitary shamans" (Roberts 2004, 342).

This is the context in which, by the end of 1963, Warhol, who had a successful career as a commercial illustrator, decided to pursue a new career as an artist. He rented a spacious ex-warehouse at East 47th Street in Manhattan and named it "the Factory”. Together with his newly employed assistant, Gerard Malanga, he started working on his art, using the silkscreen technique he had recently adopted. It was a 
technique which was originally invented for industrial use and allowed the repetitive printing of one image on multiple canvases. Most of Warhol's paintings and objects, from 1962 onwards, were made using this technique, making use of 'found images', images found in magazines and newspapers, as primary sources. The most famous were the Campbell's Soup Cans (1962), the Shot Marilyns portraits (1964) and the Brillo Box (1964). In the spirit of 'mechanical' production, a production which eliminates the artist's subjectivity in favour of a rigid set of rules, the silkscreen technique was Warhol's "machine". Positioning the copies that were made by silkscreen in an anti-hierarchical and serial grid radically equalised all images and enhanced the diminished subjective intervention on behalf of the artist. This sense of seriality was intensified by the selection of the subject matter Warhol chose to copy: some of the most common brands and cultural icons in America at the time. Warhol insisted on painting only cheap and popular "brand images": recognisable images and logos that were linked to working-class lifestyles and hence brought about a sense of working-class collective identification (Grudin 2017, 5).

The elimination of Expressionist artistic subjectivity also involved a transformation in the model of the male artist linked to it. Modernism inherited the idea of the artist as an individual and creative man, and the entire set of cultural conventions that were linked to it, from Romanticism. The artist was regarded as a strange and eccentric genius who worked alone in the studio, separated from everyday concerns. In the case of Abstract Expressionism, this anti-social model of the male artist was intertwined with another Modernist tradition - the artist as a worker. As Amelia Jones points out, since the nineteenth century, artists have adopted two main strategies to distance themselves from bourgeois society. The first was to embrace the figure of the heroic and elegant aristocrat dandy. This type of dandyism, often exemplified by the figure of French poet Charles Baudelaire, aimed to unite art and life, while rejecting the depersonalisation of modernisation (Jones 1995, 22). The second model artists chose to be identified with was simpler: the figure of the worker. Its heterosexual and virile grounds secured the artist's public acceptance, while adding democratic and productive undertones to his art (Jones 1995, 19-22).

Abstract Expressionist artists, working within the tradition of the artist as a worker, adopted many of the characteristics of the mid-century American working-class. They embraced values of "control, skill, autonomy, and independence", as respectable craftsmen used to do, while fostering "assertive and aggressive" masculinity in the spirit of the industrial worker (Meyer 2016, 6-10). According to Fionna Barber, many Abstract Expressionist painters used to wear T-shirts in public appearances, as a way to "reinforce their identification with working-class masculinity, suggesting thereby that their painting was produced through hard labour" (Barber 2004, 166). They enacted "certain forms of macho behaviour" and banned others, such as vulnerability (Barber 2004, 176). Drinking, 
fighting and bold body gestures often identified with working class "rough masculinity" (Meyer 2016, 10) became part of the public image of this generation of artists. Pollock was known as a "laconic cowboy" (Barber 2004, 154) and the Cedar Bar, where he, de Kooning, Franz Kline and others used to hang out, was described as a "facsimile of the Wild West" full of "drunken brawls, fights over women, vain boasting, and, of course, artists talk" (Katz 1996, 192).

By adopting the "language of work" and the verbal and visual rhetoric that came with it, the new generation of artists maintained the association with the model of the artist as a worker, but replaced rough masculinity with a bourgeois model of it. Frank Stella, for example, labelled himself as an 'executive artist' and adopted a business suit as his formal wear, while others, like Warhol, played with signifiers of the industrial labourer. By doing so, they achieved two things at the same time: first, they maintained the masculine virility that comes with the association of the 'worker' as a way to compensate for the loss of rough masculinity. Secondly, adopting signifiers of middle-class masculinity was an "antagonistic stance toward male artistic genius [...] parodies of the modernist conception of a stable, unified (and implicitly masculine) western subject and, by extension, of the male artist/genius" (Jones 1995, 27). On the industrial floor, the introduction of automation, machines and new managerial practices by Fordism and Taylorism led to the emasculation of "both physical and intellectual bases of working-class male identities" (Meyer 2016, 9). This forced industrial workers to re-calculate their male identities by redefining skill as "the ability to endure repetitious and monotonous tasks" within the newly mechanised factory (Meyer 2016, 8). Transforming the artistic act to a repetitive and "mechanical" procedure was a way to re-masculinise the identity of the post-war artist, while simultaneously undermining previous models.

The tension between the act of re-masculinisation through identification with the figure of the worker and its de-masculinisation through identification with bourgeois masculinity is best manifested in Warhol's case. Warhol invested in industrial and corporate rhetoric just as much as he did in his aesthetic in the early days of his career. After naming his studio 'the Factory', with its Fordist connotations, he kept referring to the industrial-corporate world in his interviews and public statements, stating that "I want everybody to be a machine" and "my assistants do all of my silkscreens" to create the illusion of the Factory's industrial production (Goldsmith 1962/1987, 24). Furthermore, during his early years as an artist, Warhol adopted a "proletarian costume" - blue jeans and a chambray work shirt (Jones 1996, 199) - which are a play between the industrial worker's gear and middle-class outfit.

However, the heavy use of industrial rhetoric stood in contradiction to the Factory's actual mode of production, which was far from industrial: there were 
no automated machines, no assembly-lines, and no wage labour. Warhol's job was closer to that of an artistic director, or rather to that of the new emasculated corporate manager, and he was mainly focused on the conception and planning of the painting and objects, and less on the execution, which was outsourced to his assistants. I suggest that Warhol radically associated himself with mechanisation and the figure of the industrial worker because of his marginalised position. His inwardness, gentle talk and fragile look implied a 'lessmanly' or queer masculinity. Together with his commercial approach to art and the 'decorative style' of his aesthetic, this feminised model of masculinity was a threat to the rough environment of the Abstract painters (Barber 2004, 348).

In his memoir, Warhol writes about the sense of rejection which he felt when he occasionally ran into this circle of artists. For them, he was too "swish" - an offensive term that meant an effeminate gay man or a "sissy" (Butt 2005, 109). He describes the environment among the Abstract painters not only as macho, but also racist, violent and excluding of anyone who was not white and straight. Major painters, even those who were secretly homosexual, as in the case of Robert Rauschenberg and Jasper Jones, tried to "look straight" (Warhol 1980, 15). ${ }^{1}$ Other accounts describe the homophobic environment in which Warhol operated, to a point where other artists did not want to be associated with him because they were afraid to be labelled as homosexuals (Butt 2005, 113).

Warhol's strategy for dealing with the situation, I argue, was to make the tension between his heavy investment in industrial rhetoric and his 'feminine' masculinity visible. That is, to enhance some 'manly' aspects of his masculinity without giving up the (coded) queer aspects of his manliness, or to "compensate" for his marginal sexuality by adopting labour-related codes of working-class (read: straight) masculinity. This was his strategy for building a career in conservative American society and in the masculinised artistic environment of the early 1960 s.

\section{Post-Fordism, Bio-political Production and the Production of Ungendered Masculinity}

In the Spring of 1965, during a trip to Paris for his show at the Ileana Sonnabend Gallery, Warhol announced his retirement from painting. “Art just wasn't fun anymore; it was people who were fascinating, and I wanted to spend all my time

1 Robert Rauschenberg and Jasper Jones are considered post-Abstract or pre-Pop artists. Warhol admired the two, who were a gay couple, but they rejected him for being too overtly gay. 
being with them, listening to them, and making movies of them", he wrote in his memoir (Warhol 1980, 142). Warhol was making movies as early as 1963, and kept painting long after 1965, but his statement marked a shift of interest for him, as an artist. The focus was now on people: their talents and lifestyles, their social dynamics and professional connections, their look and charisma, the way they carried themselves and behaved in public; in short, their performance.

This turn in Warhol's practice also meant a final shift from the position of the worker (with its industrial connotations) to the position of the manager (with its corporate connotations). Warhol started to gather people around him, not long after he moved into the Factory. This group of people, his Superstars, or rather his employees, were mostly people who had aspirations to become performing artists, models or film stars. By 1965, with Edie Sedgwick joining the group, they were already known in New York's art scene as Warhol's entourage, or the Factory People. In addition, Warhol surrounded himself with other circles of workers and collaborators, each formed and maintained for different purposes, even though their activities were constantly intertwined. Warhol recruited all these people, assigned them to work collectively on different tasks, and "fired" them when he no longer needed them. His "soft" and seemingly non-authoritative managerial style did not undermine the fact that every aspect of the Factory was linked back to him.

Warhol's Superstars not only stood at the centre of the Factory's public attention, but also at the heart of the Factory's growing production system. Their "official” job was to star in his films, but they had many other informal duties such as accompanying him to parties and openings; helping him film his movies; completing various production tasks for the Factory's everyday activity; entertaining the many guests who visited; introducing him to new talents or wealthy collectors; serving as spokespersons at public events; and providing him with ideas and inspiration for his artistic projects. Put differently, the Superstars had no official job description. Writing retrospectively about his former organisation of labour, Warhol observes: "A few people who worked with me on a fairly regular basis, a lot of what you might call free-lancers who worked on specific projects, and a lot of 'superstars' or 'hyperstars' or whatever you can call the people who are very talented, but whose talents are hard to define and almost impossible to market" (Warhol 1975, 91-92). In other texts he described the Superstars as "too gifted to lead 'regular lives', but they were also too unsure of themselves to ever become real professionals" (Warhol 1980, 71). The talent Warhol recognised in each of them lay in their personalities, either creative and communicative - "baby" Jane Holzer and Edie Sedgwick, for example - or strange and mysterious, like Nico. All the Superstars shared the desire to become famous, as well as their attentiveness to the boss's desires and needs. In many respects, Warhol's career was made possible thanks to their undefined talent. 
Warhol took advantage of his employees' subjective investment in the work to ingrain precariousness as part of the production process. He left his collaborators in a constant state of insecurity regarding their social and professional status in the Factory (Shore 2016, 37). Their working hours were flexible and adaptable. The nature of the work was undefined as well, and the number of employees was ever-changing and determined by the projects' (read Warhol's) needs. Since work was immeasurable and unquantifiable, it promoted a fluid organisation of time and space that "hybridised" the private and public spheres, work time and leisure time (Gielen 2009, 19). Some of them even turned the Factory into their temporal home. They were "unpaid, untrained, undirected, and eventually unemployed”, as Jones bluntly puts it (Jones 1996, 236). Those who stopped performing their undefined work were pushed out of the loop.

Examining this mode of production from a contemporary perspective, it is clear that Warhol implemented a post-Fordist logic of production into the production process at this stage of his artistic career. First, work was organised in a "flexible accumulation" model where Warhol, as the manager, orchestrated all facets of production and marketing. Second, work was immaterial by nature: a mode of production which prioritised immaterial goods in which "the symbolic value outweighs the use value" (Gielen 2009, 18). In the Factory, immaterial production meant that the performance of one's personality was part of the artistic outcome, and sometimes the artistic outcome itself. They were expected to be creative or innovative in the social meaning of the term, to surprise, amaze or entertain on a daily basis. This was achieved via modes of informality and play and as part of collective and seemingly non-hierarchical social dynamics, where each collaborator had to be an "active participant” (Lazzarato 1996, 134).

This mode of production was not only flexible and immaterial, but also, as Isabelle Graw points out, a form of bio-political production: the creation of value out of bodily or mental capacities of the subject by capitalisation or command over life, through technologies or mechanisms of power; production that monetised biological aspects of life, and used life itself as a source of generating value - symbolic, economic, or both (Graw 2010, 100-101). Artists, who traditionally dedicated their lives to their art, were known now to serve as a "blueprint for a post-Fordist condition that aims at the whole person" (Graw 2010, 100). But while the intertwining of life and artistic work usually took place on an individual level, even if the artist had assistants, work in Warhol's Factory was conducted through a whole set of collective performative capacities. It took cooperation and collective coordination which went beyond any recognisable modes of artistic production.

These shifts in Warhol's artistic practice and artistic subjectivity deeply changed the figure of the male artist which he developed. While some of these 
changes can now be understood as 'structural', others are linked to Warhol's personal inclinations and style of management. Writing about post-Fordist production from a gender perspective, Cristina Morini argues that cognitive labour is built on the "cultural attributes" and "historical modality of female work" (Morini 2007, 48). With these statements, Morini makes clear that she does not imply an essentialist or ahistorical perception of women's experience, but "a model of the body which is totally and traditionally subjected to the power of capitalist organization" (Morini 2007, 43). According to Morini, in post-Fordist and bio-political production, the "administration of labour", as well as its "content”, feminise the work further. In terms of administration, the demand for flexibility and adaptability, as part of the production process, reshuffles the organisation of time and space beyond the Fordist separation of life and work. The historical function of women and other 'others' in the realm of reproduction and domestic work serve as the general paradigm under post-Fordism (Morini 2007, 43-45). The content of the work is inseparable from its fluid nature: labour is taking place through cognitive, emotional and communication skills - features which resemble the modalities and logistics of care work, which does not have limits of time and space (Morini 2007, 4-48). The Factory, as a post-Fordist site, where both time and space are re-organised to fit constant artistic production, encouraged more 'feminised' aspects of labour. It is not only that women participate in the creative process, but Warhol himself gradually gave up 'masculine' attributes such as his "proletarian costume" and the industrial-like display.

The feminisation of labour, which is inherent to bio-political production, as it was played out in the Factory, was backed by a public discussion about the emasculation of the "white-collar" profession in general and the figure of the corporate manager, in particular. The shift towards "managerial capitalism" meant less focus on men's physical abilities and gave more importance to their social, cognitive and emotional skills. Individuality and autonomy, the cornerstones of American masculinity as it was developed since the nineteenth century, had to be expressed within corporate life, in a corporative manner (Kimmel 1996, 173). As part of this process, corporate culture "insisted upon a refinement of manners that seemed antithetical to traditionally masculine qualities like aggressiveness and competitiveness" (Forth 2008, 155). These "feminizing' constraints of corporate culture” (Forth 2008, 209) meant not only cooperation and equality among co-workers, but also an acknowledgment of the workers' need for self-expression and self-actualisation. According to Eva Illuz, as emotions, communication and self-consciousness became essential parts of the corporate work process, they oriented male workers to a model more closely connected to the traditional female one (Illuz 2007, 16). It softened traditional masculine features and blurred gender divisions. 
As the Factory was becoming a more 'feminine' space, due to its corporative and communicative modes of production, Warhol's figure took the direction of the corporate bachelor - the unmarried male that is not obliged to fulfil the role of domestic provider. As Forth puts it, "the bachelor thus enjoyed the best of both worlds: while his impeccable taste in food, music, clothes and furniture rendered him even more 'civilised' than women, he enjoyed a freer approach to sexual passion than his more domesticated friends" (Forth 2008, 209). Translated into gendered models of artistic subjectivity, Warhol's version of the bachelor was that of the bachelor-dandy - "a freakish, queer other" with an "awkward, sissy-boy appearance” (Butt 2005, 118). The bachelor, as an "ambiguously gendered figure", became elided with "an equally ambiguous corporate executive in the homosocial business place" (Jones 1996, 255). If the corporate bachelor marks an alternative to 'domesticated' masculinity, the bachelor-dandy explores nonnormative life patterns, and is hence a threat to bourgeois society.

While Warhol's paintings and films kept his sexuality coded, the lifestyle in the Factory became a challenge to the heteronormative (read: bourgeois) lifestyle. More and more people visited the space, day and night, and used it for different needs: drug use, execution of creative projects, random sexual encounters, or most commonly, a place to hang out. Everyday life - personal style, relationships, social gathering and modes of behaviour, all became part of the Warhol brand and, hence, inseparable part of the artistic act. In terms of production, Warhol became involved not only in visual art and films, but also in music and fashion. He was now running a full production house as well as social club in a seemingly cooperative and anti-hierarchical managerial style. Throughout this process he became "an ambiguously gendered figure [. . .] bachelor executive, the man-not-desiring-women, the camp dandy" (Jones 1996, 255). By 1965/66, his look evolved into that of the "androgynous" figure with his "French sailor look" (Breton-striped sailor top) and later his leather jacket, equally associated with the heterosexual "macho" rebel (Marlon Brando) and BDSM. "Dandyism provided an interpretative screen through which a knowledge of Warhol's queerness could be avowed, but one entertained only in, and as, a process of simultaneous disavowal”, writes Gavin Butt $(2005,154)$. It was a way for Warhol to mark his sexuality while embracing gender ambivalence and asexuality.

However, if the meaning of masculinity is reformulated in response to social and economic changes (Baron 2006, 145), it can be argued that Warhol's androgyny, with its inherent ambivalence, was his strategy to maintain power and control over his career. According to Jones, the equivocation of his 'feminine' and seemingly democratic and anti-hieratical managerial style was also a 
form of covert power that maintained the patriarchal power relations in the Factory:

With his small-scale camera and crew, Warhol sought to convert the studio into the Studio (via the Factory) - appearing to emulate the patriarchal Hollywood family system dominated by the father/mogul who must adjudicate among the bickering children he has created. Yet Warhol famously refused to adjudicate, preferring the covert power of the manipulator, a gender role typecast as the catty female (though available to any sex that covets its less visible tools). This was clearly an inversion of the managerial models that were dominant in industries of the time, and constituted another mode of ambiguation in the Factory's production.

(Jones 1995, 235)

Warhol's refusal to adjudicate, understood in this context as feminine, was a strategy for manipulation and obfuscation. While Jones is referring here to his artistic method of filmmaking, the same can be argued for the state of social and economic instability he maintained in the Factory (as mentioned earlier). Warhol's employees were emotionally and economically exploited and enjoyed only the fringe benefits that came from working in the creative industry (Gill and Pratt 2008, 13-14). Power in the Factory, exactly like Warhol's sexual orientation, was coded (Jones 1996, 242-243).

This does not mean that patriarchy was undermined. As Connell points out, men can receive "the benefits of patriarchy without enacting a strong version of masculine dominance" - for instance, this applies to gay men who might have a more "ambivalent" relationship to patriarchy (Connell and Messerschmidt 2005, 832). That "patriarchal dividend" (Connell 1995, 79) was gained from the subordination of women as well as other masculinities, hence Warhol's covert power was felt among the Factory people regardless of their gender. It did not challenge the heterosexist ideological structure of the patriarchal culture of the larger economic order (Berger, Walls and Watson 1995, 2).

No wonder, then, that behind his back, Warhol's notorious nickname was Drella - a combination of Dracula and Cinderella. The blend between the frightening vampire and the lucky princess precisely captured the tension between Warhol's 'feminine' and 'masculine' features. Given the meanings of these gendered aspects, when translated into models of artistic subjectivity (and modes of production), I argue that Drella expresses something deeper: the complex intersection between Warhol's model of masculinity and his model of artistic production. On the one hand, 'feminine' masculinity goes through an overt process of androgynisation and uses strategies of covert power and passivity to maintain unofficial hierarchies and exploit workers. On the other hand, a model of the artist as a facilitator of a permissive social space for the queer community and the artistic underground scene which, by means of withdrawal, gives visibility to anti-bourgeois forms of life. The more Warhol experimented with managing 
bio-political production and producing un-normative forms of life, the more his masculinity became ungendered (but no less patriarchal). If one is "becoming gendered in and through work" (Weeks 2011, 10), Warhol's adaptation of corporate managerial strategies within the realm of art production intensified both emasculation and exploitation.

\section{Conclusion}

The figure of the artist as an emasculated, yet authoritative, manager, was adopted by Warhol for the rest of his career. As an acclaimed artist and an international mega-star, this figure was highly influential in at least two ways. First, it allowed new generations of artists to drop the traditional masculine image of the heroic artist and present more diverse types of artistic masculinities. Second, it opened up a new set of positions artists can take in society - some of them are more "masculine" (the artist as a constructor) and some are more "feminine" (the artist as a social worker). Warhol's dynamic play between gender identity and artistic practice opened the door for new types of artistic subjectivities, and, as a result, new types of artistic careers.

A direct reference to the link between masculinity and artistic practice can be found deep within Warhol's career. In 1978, he created the Oxidation Painting, also known as the Piss Painting. This series was his first attempt to create an abstract painting in the spirit of Abstract Expressionism, but as Warhol himself made clear (Carrier 2002, 73), it was a parody of the Expressionist style in general and of Pollock's art in particular. To create the painting, Warhol invited a group of friends to urinate on a canvas covered with copper paint. The uric acid removed parts of the paint or changed its colour, creating an effect of abstraction. By replacing paint with urine, dripping with pissing, and the figure of the "heroic" Abstract male artist with a group of queer colleagues, Warhol ridiculed Pollock's expressive gesture. But the Piss Painting was also an act of revenge: a victory of the marginal (read: homosexual, feminine) model of masculinity over that of a rough one. It exposed the close association between modes of artistic production and models of masculinity. Manipulations in the former led to change of meaning in the latter; one was shaping the other.

Using these ideas to re-examine the most formative years in Warhol's artistic career, I argue that it is impossible to grasp his changing conception of masculinity without articulating the transformations in his artistic practices and their social and cultural meaning. Eliminating Modernist artistic subjectivity and the artistic practices, which were attached to it, led to the emergence of a new figure 
of the male artist. This model initially maintained some signifiers of previous models of masculinity, namely, the identification with the artist as a worker. As I suggested, Warhol's great investment in industrial rhetoric and aesthetic helped compensate for his "swish" or less-manly masculinity.

As the 1960s progressed, Warhol adopted post-Fordist and bio-political forms of production that supported and enhanced more 'feminine' attributes, allowing him to become an "androgynous" figure, one who relates to the tradition of the artist as dandy. This process took place in tandem with Warhol's shift of position from the "industrial" worker to the "corporate" manager - a figure which signifies the fear of emasculation in post-war America. This, however, does not mean that patriarchy was eliminated. As a system of control and subordination, patriarchy was maintained, but now operated in more complex and sophisticated ways than before.

\section{References}

Barber, Fionna. 2004. "Abstract Expressionism and masculinity." In Varieties of Modernism, edited by Paul Wood. 147-186. New Haven: Yale University Press in association with the Open University.

Baron, Ava. 2006. "Masculinity, the Embodied Male Worker, and the Historian's Gaze." International Labor and Working-Class History (69): 143-160.

Berger, Maurice, Brian Wallis, and Simon Watson. 1995. Constructing Masculinity. New York: Routledge.

Buchloh, Benjamin. 2001. “Andy Warhol: One Dimensional Art.” In Andy Warhol, edited by Annette Michelson and Benjamin Buchloh. Cambridge: MIT Press.

Butt, Gavin. 2005. Between You and Me: Queer Disclosure in the New York Art World, 1948-1963. London: Duke University Press.

Carrier, David. 2002. Rosalind Krauss and American Philosophical Art Criticism: From Formalism to beyond Postmodernism. Westport: Praeger.

Connell, Raewyn, and James W Messerschmidt. 2005. "Hegemonic Masculinity: Rethinking the Concept." Gender \& Society 19(6): 829-859.

Connell, Raewyn. Masculinities. 1995. Berkeley: University of California Press.

Crimp, Douglas. 1999. "Getting the Warhol we Deserve.” Social Text 59: 49-66.

Crimp, Douglas. 2012. "Our Kind of Movie": The Films of Andy Warhol. Cambridge: MIT Press.

Doyle, Jennifer. 2015. “Just Friends: On the Making of Pop Out: Queer Warhol.” In Otherwise: Imagining Queer Feminist Art Histories, edited by Amalia Jones and E. Silver. 50-70. Manchester: Manchester University Press.

Forth, Christopher E. 2008. Masculinity in the Modern West: Gender, Civilization and the Body. New York: Palgrave Macmillan.

Gielen, Pascal. 2009. The Murmuring of the Artistic Multitude: Global Art, Politics and PostFordism. Amsterdam: Valiz.

Gill, Rosalind, and Andy Pratt. 2008. "In the Social Factory?: Immaterial Labour, Precariousness and Cultural Work." Theory, Culture \& Society 25(7-8): 1-30. 
Goldsmith, Kenneth. 2004. I'll be Your Mirror: The Selected Andy Warhol Interviews 1962-1987. New York: Carroll \& Graf.

Graw, Isabelle. 2010. "When Life Goes to Work: Andy Warhol.” October 132 (Spring): 99-113. Grudin, Anthony E. 2017. Warhol's Working Class: Pop Art and Egalitarianism. Chicago: The University of Chicago Press.

Harvey, David. 1990. The Condition of Postmodernity: An Inquiry into the Origins of Cultural Change. Oxford: Blackwell.

Illuz, Eva. 2007. Cold Intimacies: The Making of Emotional Capitalism. Cambridge: Polity. Jones, Amelia. 1995. “'Clothes Make the Man': The Male Artist as a Performative Function.” Oxford Art Journal 18(2): 18-32.

Jones, Caroline A. 1996. Machine in the Studio: Constructing the Postwar American Artist. Chicago: University of Chicago Press.

Joseph, Branden. 2005. “The Play of Repetition - Andy Warhol's Sleep.” Grey Room 19: 22-53. Katz, Jonathan. 1996. "The Art of Code: Jasper Jones \& Robert Rauschenberg." In Significant Others: Creativity and Intimate Relationship, edited by Whitney Chadwick and Isabelle de Courtivron, 189-207. London: Thames and Hudson.

Kimmel, Michael. 1996. Manhood in America: A Cultural History. New York: Free Press.

Lazzarato, Maurizio. 1996. "Immaterial labor." In Radical Thought in Italy: A Potential Politics, edited by Paolo Virno and Michael Hardt, 132-147. Minneapolis: University of Minnesota Press.

Marchand, Roland. 1998. Creating the Corporate Soul: The Rise of Public Relations and Corporate Imagery in American Big Business. Berkeley: University of California Press.

Meyer, Stephen. 2016. Manhood on the Line: Working-Class Masculinities in the American Heartland. Urbana, Chicago, and Springfield: University of Illinois Press.

Molesworth, Helen. 2003. "Work Ethic." In Work Ethic, edited by Helen Molesworth, 25-52. Pennsylvania: Pennsylvania State University Press.

Morini, Cristina. 2007. "The Feminization of Labour in Cognitive Capitalism.” Feminist Review 87: 40-59.

Regev Ronny. 2018. Working in Hollywood: How the Studio System Turned Creativity into Labor. North Carolina: North Carolina University Press.

Roberts, John. 2007. The Intangibilities of Form: Skill and Deskilling in Art After the Readymade. London: Verso.

Roberts, John. 2004. "Warhol's Factory: Painting and the Mass-Cultural Spectator." In Varieties of Modernism, edited by Paul Wood, 338-361. New Haven: Yale University Press in association with the Open University.

Rosenberg, Herold. 2003. “The American Action Painters”. In: Art in Theory 1900-2000: An Anthology of Changing Ideas, edited by Charles Harrison and Paul Wood. 589-592. New York: Blackwell Publishing.

Schoonover, Karl. 2012. "Wastrels of Time: Slow Cinema's Laboring Body, the Political Spectator, and the Queer." Framework 53(1), Spring: 65-78.

Shore, Stephan. 2016. Factory people. London: Paidon.

Warhol, Andy. 1980. POPism: The Warhol Sixties. Edited by Pat Hackett. Toronto: Harcourt. Warhol, Andy. 1975. The Philosophy of Andy Warhol: (From a to B and Back again). New York: Harcourt Brace Jovanovich.

Weeks, Kathi. 2011. The Problem with Work: Feminism, Marxism, Antiwork Politics, and Postwork Imaginaries. London: Duke University Press. 